ISSN 1996-1073

www.mdpi.com/journal/energies

Article

\title{
Field Experiments of PV-Thermal Collectors for Residential Application in Bangkok
}

\section{Thipjak Nualboonrueng ${ }^{1, *}$, Pongpith Tuenpusa ${ }^{2}$, Yuki Ueda ${ }^{1}$ and Atsushi Akisawa ${ }^{1}$}

1 Tokyo University of Agriculture and Technology, 2-24-16 Naka-cho, Koganei-shi, Tokyo 184-8588, Japan; E-Mails: uedayuki@cc.tuat.ac.jp (Y.U.); akisawa@cc.tuat.ac.jp (A.A.)

2 Rajamangala University of Technology, 39 Muh1, Rangsit-Nakhonnayok Road, Klong Hok, Thanyaburi Pathum Thani, 12110, Thailand; E-Mail: pongpith@rmutt.ac.th

* Author to whom correspondence should be addressed; E-Mail: thipjak@yahoo.com;

Tel./Fax: +66-2564-7000.

Received: 6 February 2012; in revised form: 25 March 2012 / Accepted: 11 April 2012 /

Published: 23 April 2012

\begin{abstract}
This study presents experimental results on Photovoltaic-thermal (PVT) solar systems, the commercial photovoltaic (PV) panels used as solar absorbers in PVT collectors, which are amorphous and multi-crystalline silicon. Testing was done with outdoor experiments in the climate of Bangkok corresponding to energy consumption behavior of medium size Thai families. The experimental results show that the thermal recovery of amorphous silicon PVT collector is almost the same as that of multi-crystalline silicon PVT collectors while electricity generation of multi crystalline silicon PVT is 1.2 times as much as that of amorphous silicon PVT. The maximum of heat gain from the PVT systems were obtained in March in summer. It was found that PVT collectors of unit area annually produced $1.1 \times 10^{3} \mathrm{kWh} / \mathrm{m}^{2}$.year of heat and $55-83 \mathrm{kWh} / \mathrm{m}^{2}$.year of electricity, respectively. The results show that annual average solar factor of hot water supply is 0.45 for unit collector area. Economical evaluation based on energy costs in Thailand was conducted, which estimated the payback time would be 7 and 14 years for a-Si PVT and mc-Si PV, respectively.
\end{abstract}

Keywords: PVT collector; performance measurement; Thailand climate; photovoltaic cell; payback years 


\section{Nomenclature}

A aperture area of PVT collector, $\mathrm{m}^{2}$

C specific heat, $\mathrm{kJ} /(\mathrm{kg} \cdot \mathrm{K})$

$\mathrm{G}$ incoming solar radiation, $\mathrm{kW} / \mathrm{m}^{2}$

I current at maximum power point of PV panel, A

Q energy, kJ

$\mathrm{T}$ temperature, $\mathrm{K}$

$\mathrm{V}$ voltage at maximum power point of PV panel, A
Greek Symbols

$\eta \quad$ efficiency

Subscripts

c heat

e electrical

i inlet

$\mathrm{m}$ maximum

o outlet

th thermal

\section{Introduction}

\subsection{Background}

At present the global demand of energy usage is increasing dramatically as can be seen from the oil prices that have increased significantly. The governments of many countries have attempted to develop their own policies and research work in the area of renewable energy utilization. Solar energy is one of the solutions to reduce the national energy consumption on fossil fuels and it becomes very often their first choice of government policy. Recently, besides PV panels that can produce electricity and solar water heating that can produce heat in the form of hot water or hot air, PVT (Photovoltaic-Thermal) solar technology has been developed to serve both heat and electrical demand. PVT collectors are devices that combine both electrical and heat technology together. The normal PV panel has been assembled with heat extraction devices to be PVT collector that can generate simultaneously both types of energy required by most consumers.

Typical PV modules can only convert $10-20 \%$ of solar radiation to electricity while some part is reflected back to the sky and the reminding solar energy will be transformed into heat. Also, for PVT collector, the absorbed solar radiation is only partly converted to electricity by PV cells while the other excess energy will be transformed to heat. For PVT system the generated heat will be utilized as low temperature heat energy corresponding to its application. PVT collector concept offers an opportunity to increase overall system efficiency by using the waste heat that generated from PV module. Since it is well known that the efficiency of PV cell decreases with an increase in operating temperature, electrical energy generation should be theoretically improved by the cooling effect of heat extracting part of the PVT collector. Thailand has much potential for solar energy collection which is on average $18.2 \mathrm{MJ} / \mathrm{m}^{2}$ per day for tropical climate [1]. The ambient temperature in summer can typically reach over $40^{\circ} \mathrm{C}$ while the average wind speed is usually quite slow. The residential sector in Thailand now consumes both electricity and heat and is a major part of energy consumption of national energy in Thailand. The usage of PVT technology especially for the residential sector is expected to replace conventional fuel consumption with renewable energy effectively in Thailand. 


\subsection{Literature Survey}

Several experimental studies were analyzed in the past, Chow, He and Ji [2] studied the PV's performance by PVT technology using water as a coolant by numerical analysis and experiments. They constructed flat-box type PVT collectors and tested them under the climate of China. The system was designed for residential application running under thermosyphon mode. Their experimental rig consisted of a flat-box PVT collector having an aperture area of $1.64 \mathrm{~m}^{2}$ and a thermally-insulated 100 liter water storage tank. Polycrystalline silicon solar cells with conversion efficiency of $14.5 \%$ were used as solar absorbers. The overall performance of the PVT collector system was reported to be promising for providing an alternative means of energy for domestic sectors of China. Bakker et al. [3] reported the outdoor performance of uncovered PVT panels tested in The Netherlands. Their PVT panels were built from multi-crystalline silicon cells and laminated between a copper sheet-and-tube absorber and low-iron glass sheet. Their PVT panels had an area of $80 \times 80 \mathrm{~cm}^{2}$ and were framed with standard aluminum PV frames. Their results showed that for electrical performance measured by flash tester, the module efficiency was found to be $11.2 \%$ as expected. For thermal performance, the outdoor testing result reported that the loss was much higher than expected. Tripanagnostopoulos et al. [4] reported the outdoor in place performance of various kinds of PVT collector in Cyprus by using typical commercial PV modules. Their results showed that PV cooling can increase the electrical efficiency of PV modules and the total efficiency of the system. They also reported that improvement of PVT can be achieved by using an additional glazing to increase thermal output and a booster diffuse reflector can increase both of electrical and thermal output. Saitoh et al. [5] reported a field experiment and analysis on PVT solar collector in Sapporo, Japan. Their experiments were conducted under constant temperature of water supply with crystalline silicon PVT collector and compared with PV panel and normal solar collector. Field experiments were carried out from November 1998 to October 1999 at a low energy house at Hokkaido University. The results showed that the PVT collector was roughly equivalent to normal PV in electrical efficiency and that the PVT collector was lower than normal solar collectors in thermal efficiency. Nakajima et al. [6] investigated the spectral effect of amorphous silicon solar cells on outdoor performance in various locations in Japan. They reported that the output current of a-Si module depended not only on module temperature and annealing effect but also the spectral effects of sunlight such as seasonal variations of the air mass and atmospheric conditions.

Since the performance of PV or the thermal systems depend on the ambient temperature and the solar spectrum, the R\&D activities have been carried out at various locations. As mentioned above in our literature review, most of work was carried out Europe and a few studies have been done in East Asia such as Japan and China. On the other hand, no work has been carried out in tropical climate regions where: (1) the ambient temperature is very hot throughout the year which should strongly effect PV performance and (2) the solar spectrum is suitable for PV such as amorphous silicon solar cell which is very sensitive to the short wavelength spectrum. Therefore the R\&D on PVT systems in tropical climate regions should be carried out to evaluate possible performance.

Taking into account the above-mentioned point of view, this work has focused on a field experiment of PVT performance at specific locations in the tropical climate of Bangkok the system performance with two types of commercial PV panel using as absorber of PVT collectors. 
Advantages of PVT systems are:

- Higher energy yield per square meter of surface area.

- Simultaneous production of both electricity and heat by one device.

- Reduced manufacturing and installation cost.

It is obvious that both electricity and heat are fundamental needs for all consumers. PVT technology can be a good choice to use solar energy on efficient way and, therefore, it is expected to be a promising technology in the future.

\subsection{Objective}

The objective of this study is to investigate the quantitative energy output of PVT collectors that use different types of PV cells as the solar absorber in the climate of Thailand. The comparison of PV cells is also conducted to clarify what cell is suitable for PVT collectors for the tropical climate conditions. Multi-crystalline (mc-Si) and amorphous silicon (a-Si) cells were examined. PVT performance in Thailand is discussed in comparison with that in Europe in this paper.

\section{The Experimental System}

\subsection{PVT Collector}

In this study, the tested PVT collectors are produced from two available commercial (a-Si and mc-Si) PV panels. The PV panels have been used as solar absorbers of PVT collectors. The configuration of PVT collector is shown in Figures 1 and 2. The configuration of PVT in this study is PV-on-sheet-and-tube type which is the most practical and easier to manufacture as Zondag et al. [7] mentioned in their paper. PV-on-sheet-and-tube type PVT can be described in detail as follows. The structure of used PV panels in this paper has a glass as the top surface and polymer sheet as back the encapsulation. PV panels have been adhered on the top of metal plate by thermal epoxy. There are longitudinal circular channels beneath the metal plate which are prepared for attaching the circular copper tubes. The rear side copper tubes has rock wool insulator layer to prevent bottom heat losses. The low iron and high transparency glass cover was used to reduce the heat loss from the top surface of PV to ambient caused by wind convection. The PVT collector assembled with top glass cover was considered in this study. The nominal conversion efficiency of PV panels is $6.3 \%$ and $12.7 \%$ for a-Si and mc-Si PV, respectively.

Figure 1. Configuration of PVT collector.

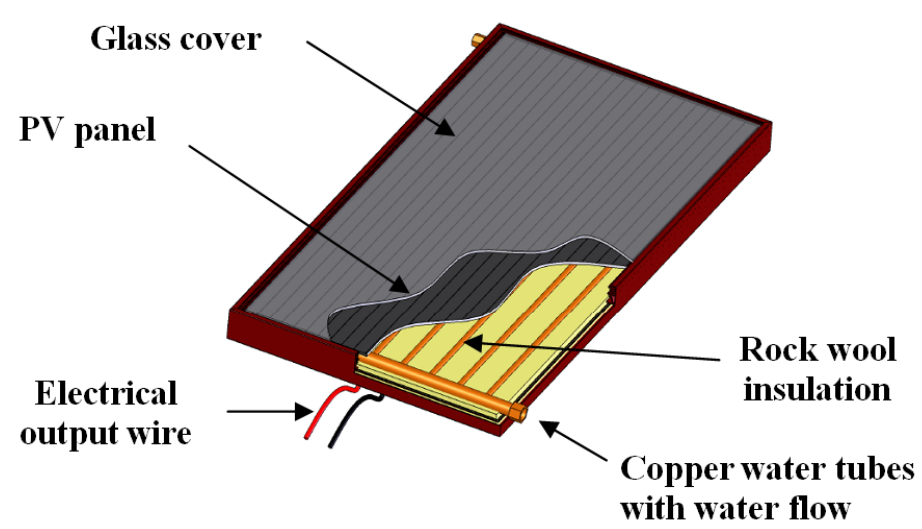


Figure 2. Cross sectional PVT collector.

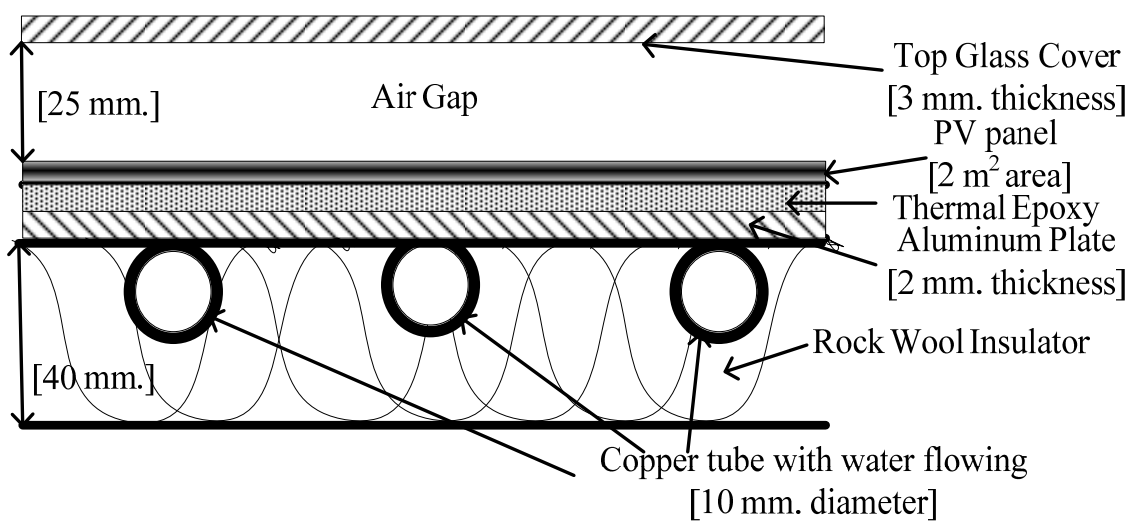

\subsection{Experimental Setup}

Figure 3 shows the schematic diagram of the system and Figure 4 shows the experimental rig. Each system consists of a series of PVT panels having $2 \mathrm{~m}^{2}$ of total aperture area and the tilt angle of the panel is $15^{\circ}$. The system was equipped with a two layers of stainless steel hot water storage tank with insulator of 120 liters. The water draw pattern was controlled to simulate measured data of water consumption for a medium size family living in Bangkok. Electricity produced from the system was connected to load and was measured by watt meters (with accuracy $\pm 0.5 \%$ of maximum value). The circulation pump for water in the collector loop is controlled by a differential controller to prevent heat rejection from the storage tank to ambient via the collector and the water flow rate was at $5.6 \times 10^{-3} \mathrm{~kg} / \mathrm{s}(20 \mathrm{~kg} / \mathrm{h})$. The water flow meters with accuracy $\pm 5 \%$ have been used for mass flow measurements for each PVT system. Thermocouple type K have been used as temperature sensors were positioned at the inlet and outlet of the collector. Second class pyranometer (with $\pm 10 \mathrm{~W} / \mathrm{m}^{2}$ accuracy) was installed in co-planar with the collector surface to measure solar radiation. All of physical signals were recorded by a computer at 5 min time intervals. The experimental system was installed on the roof of a building in Rajamanggala University located in Pathumthani province near Bangkok. System input parameters are shown in Table 1.

Figure 3. Schematic of PVT system.

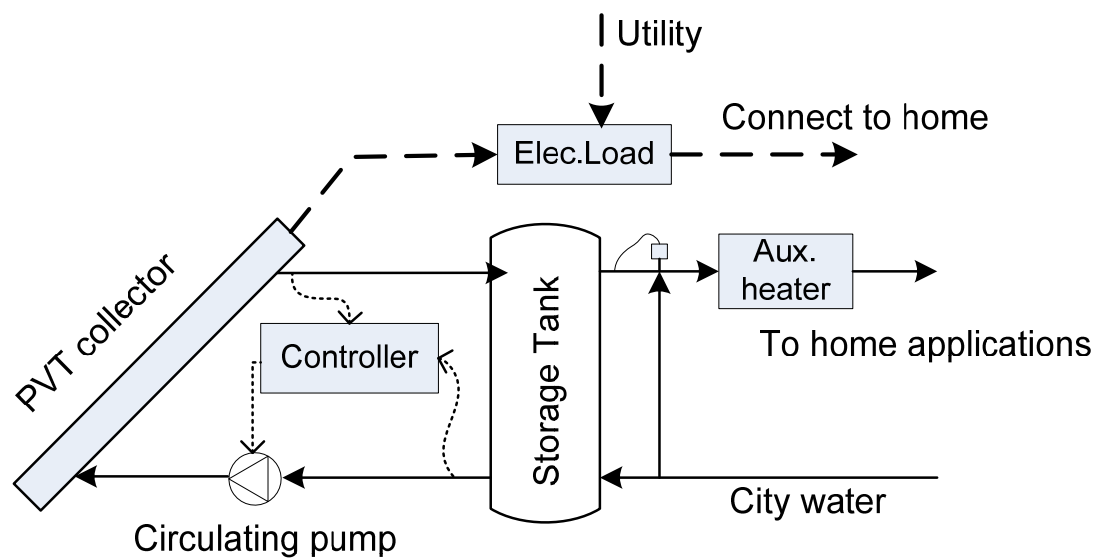


Table 1. System input parameters.

\begin{tabular}{lll}
\hline Item & a-Si PVT & mc-Si PVT \\
\hline Collector area $\left(\mathrm{m}^{2}\right)$ & 0.9 & 1.96 \\
Packing factor of PVT collector & 0.9 & 0.9 \\
Working fluid thermal capacitance $(\mathrm{kJ} / \mathrm{kg} \cdot \mathrm{K})$ & 4.19 & 4.19 \\
Nominal efficiency of PV panel $(\%)$ & 6.3 & 12.7 \\
Collectors slope (degree) & 15 & 15 \\
Number of glass covers & 1 & 1 \\
Glass cover transmittance & 0.92 & 0.92 \\
Storage tank volume $\left(\mathrm{m}^{3}\right)$ & 0.12 & 0.12 \\
Temperature coefficient of PV cell efficiency & -0.0023 & -0.0043 \\
Loss coefficient of bottom and edge losses $\left(\mathrm{J} / \mathrm{s} \cdot \mathrm{m}^{2} \cdot \mathrm{K}\right)$ & 0.31 & 0.31 \\
\hline
\end{tabular}

Figure 4. Experimental rig.

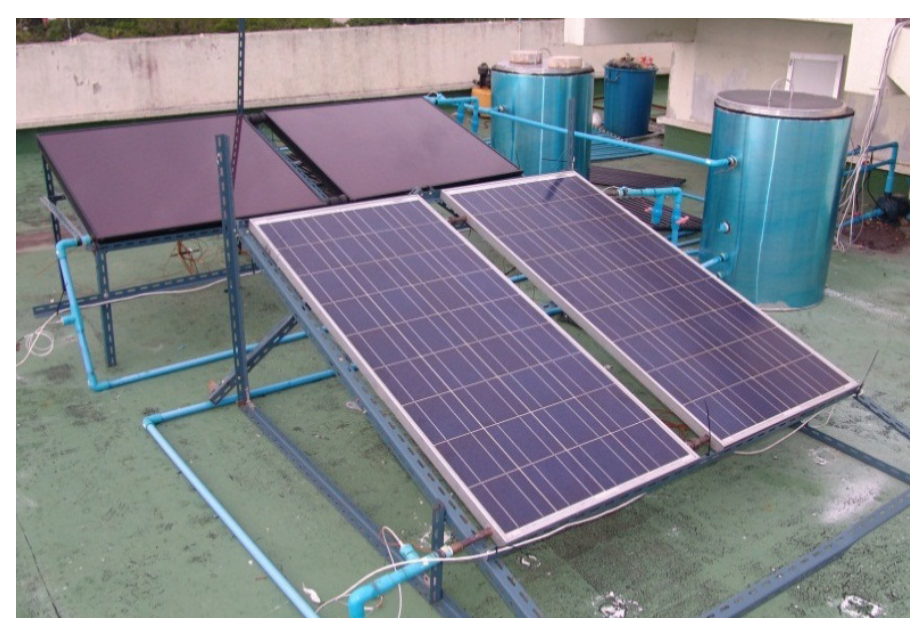

The heat output, electricity output, thermal efficiency and electrical efficiency of PVT collectors are expressed with the following equations. Here integrals mean monthly or yearly summation:

$$
\begin{gathered}
Q_{c}=\int \dot{m} C_{p}\left(T_{o}-T_{i}\right) d t \\
Q_{e}=\int I_{m} V_{m} d t \\
\eta_{t h}=\frac{Q_{c}}{A \int G d t} \\
\eta_{e}=\frac{Q_{e}}{A \int G}
\end{gathered}
$$

\subsection{Environment Conditions}

The measured solar radiation, ambient temperatures are shown in Figure 5. The figure shows the monthly accumulative of solar irradiation and monthly average of ambient temperature, the figure shows that the solar radiation has maximum during summer (from March to June) and minimum during winter 
(December and January). For ambient temperature, it can be seen that the curve has a bell shape with maximum values during summer and minimum values in winter. Figure 6 shows the monthly average of city water temperature, which indicates that the maximum water temperature occurred during March to June. The amount of daily hot water consumption is assumed to be 160 liters per day and the time of use is shown in Figure 7. Both patterns of water consumption and average monthly city water temperature in Bangkok were measured by Rajamangala University of Technology, Thailand.

Figure 5. Solar radiation and ambient temperature in Bangkok.

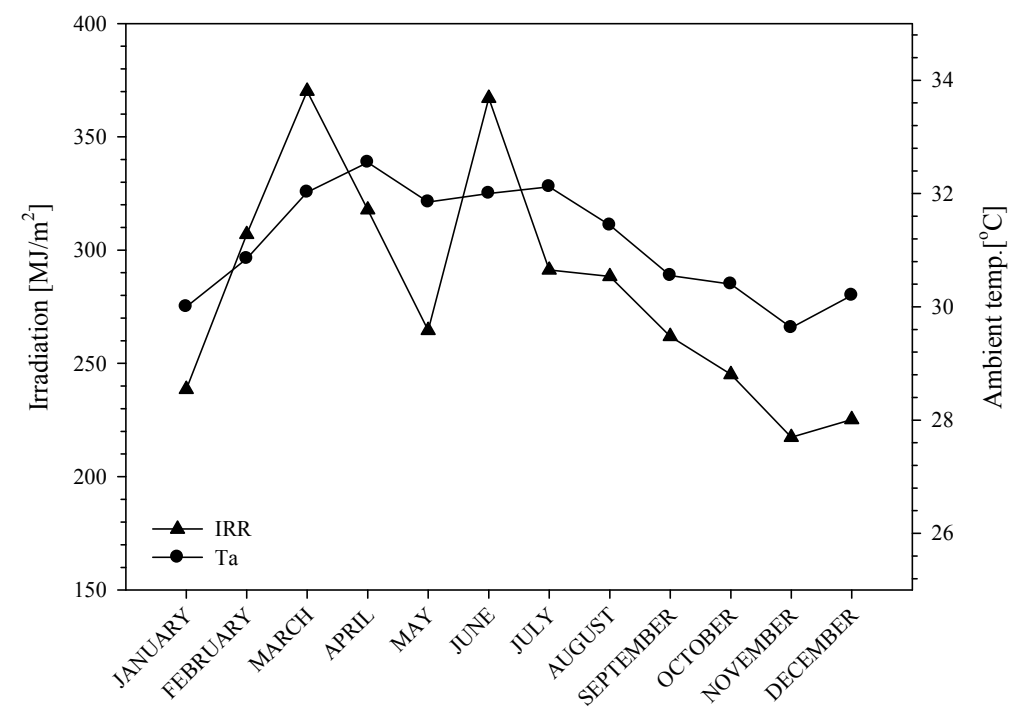

Figure 6. Monthly city water temperature profile in Bangkok.

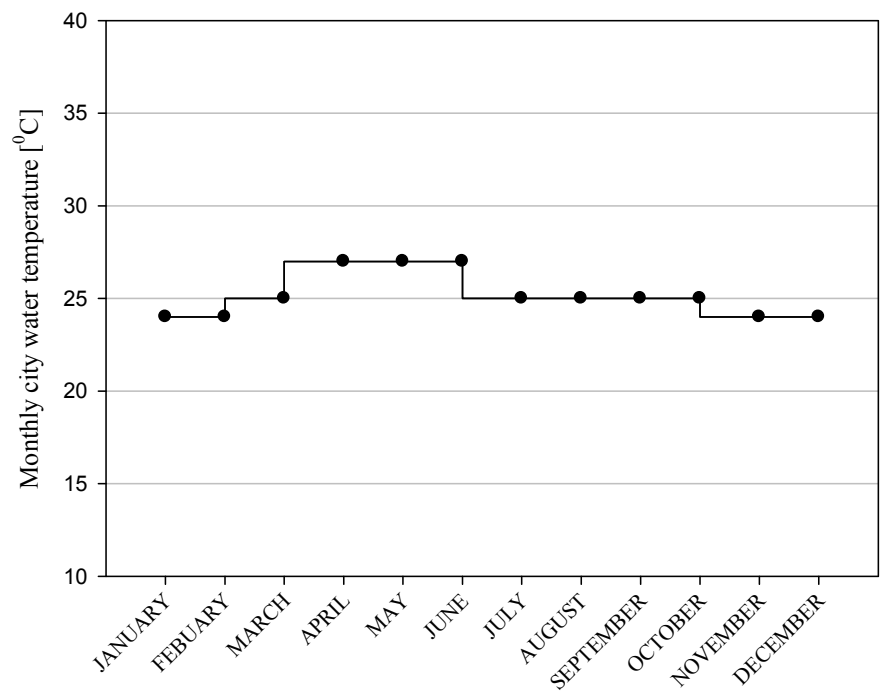


Figure 7. Average daily water consumption profile.

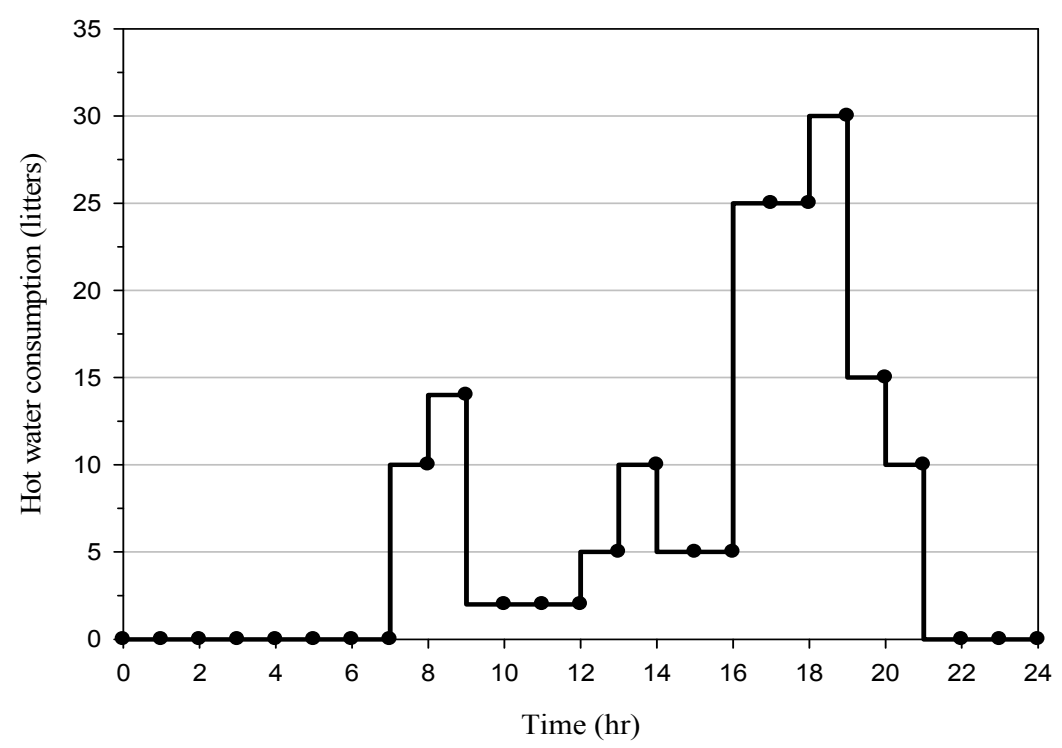

\section{Experimental Results}

This part presents the experimental results of PVT systems in Bangkok's climate. The results can be used to predict the performance of PVT systems working in Bangkok. PVT collectors produce hot water to be consumed by a dummy heat load to emulate hot water use in a medium-sized family while the generated electricity was connected to a dummy load as well via DC/AC inverter.

\subsection{Daily Energy Production of PVT Systems}

Figure 8 shows the energy production of the PVT systems on a randomly selected day in March. The figure shows that the thermal and electrical energy production curves in same shape with solar radiation as expected.

Figure 8. Daily energy production of PVT systems.

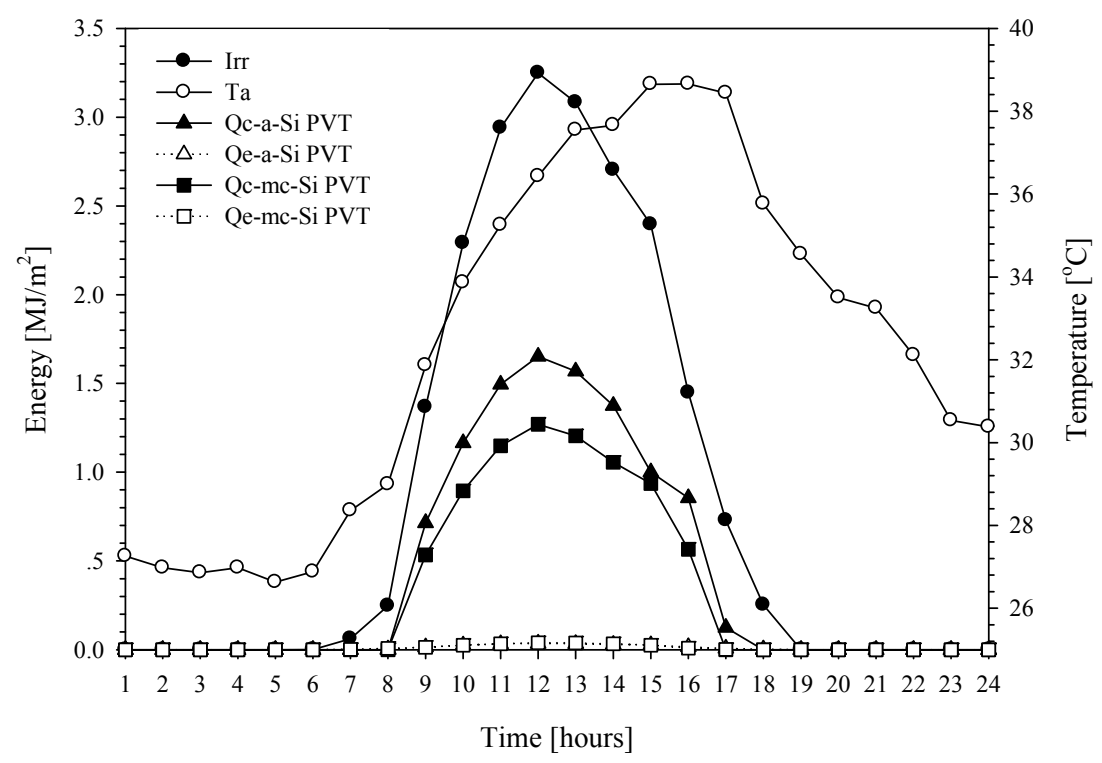


The heat production of a-Si PVT is higher than that of a mc-Si PVT. Moreover, the heat production seems dependent on with solar radiation rather than ambient temperature. The maximum of thermal energy are obtained at 12:00 AM for both type of PVT systems.

Figure 9 shows the electrical energy production of both type of PVT system, there are also bell shapes with solar irradiation. It can be noted that when the time after 2 PM. the electrical production of mc-Si probably rapidly drop rather than a-Si PVT that resulted from the effect of high ambient temperature (over $37^{\circ} \mathrm{C}$ ).

Figure 9. Daily electrical production of PVT systems.

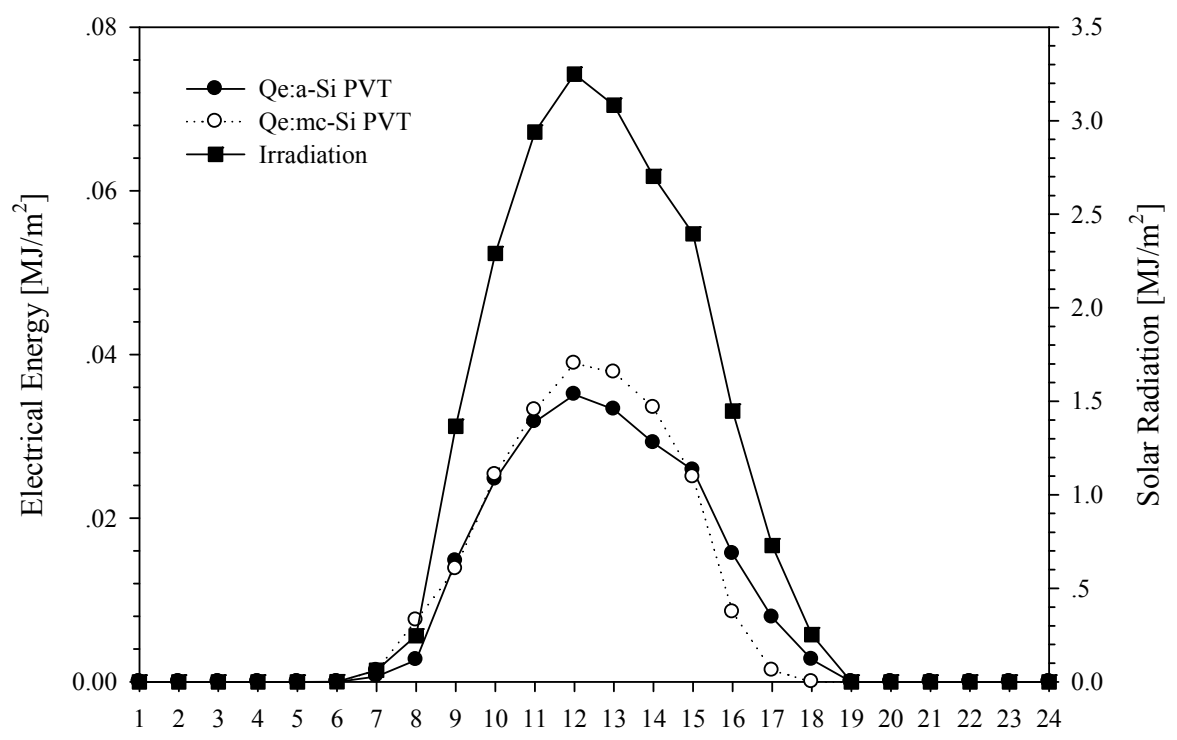

\subsection{Monthly and Annually Energy Production of PVT Systems}

The maximum values of thermal energy output (Qc) and electrical energy output (Qe) were investigated at a water flow rate of $20 \mathrm{~kg} / \mathrm{h}$ for both types of PVT collectors. Monthly energy outputs for both types of PVT systems have been shown in Figures 10 and 11.

Figure 10. Energy production of a-Si PVT collector.

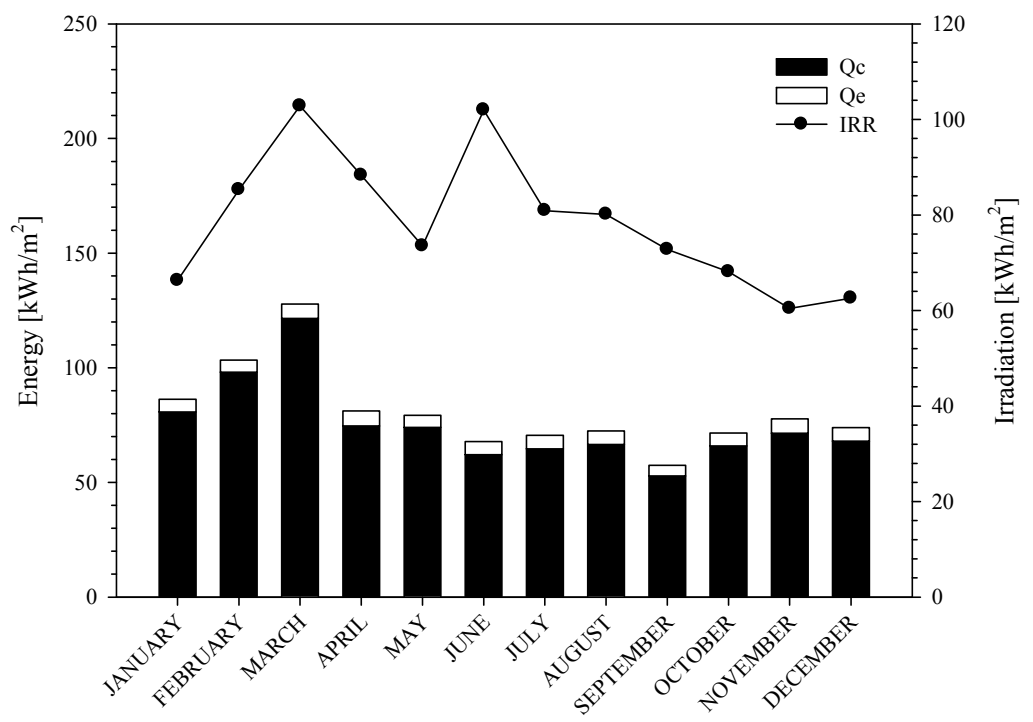


Figure 11. Energy production of mc-Si PVT collector.

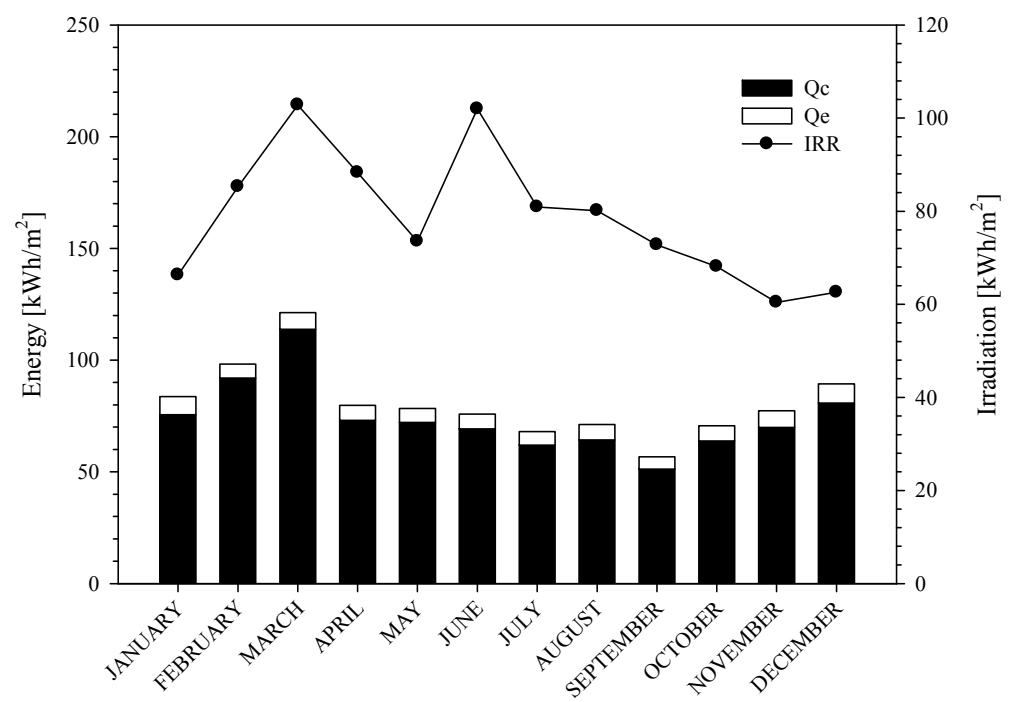

With considering the condition of the measurement and specified location, the monthly energy outputs seem consistent with the pattern of solar radiation and ambient temperature. It should be noted that the exceptional behavior in June is due to rainy season in Thailand. The quantitative value can be used for system designer in the future with the residential application.

The annual energy outputs are shown in Table 2, indicating the annual energy gain was used to calculate payback years that are shown in Table 3.

Table 2. The annual energy output of PVT collectors.

\begin{tabular}{lll}
\hline & a-Si PVT & mc-Si PVT \\
\hline Thermal energy output $\left[\mathrm{kWh} / \mathrm{m}^{2}\right]$ & $1.2 \times 10^{3}$ & $1.1 \times 10^{3}$ \\
Electrical energy output $\left[\mathrm{kWh} / \mathrm{m}^{2}\right]$ & 61 & 72 \\
\hline
\end{tabular}

Table 3. Payback of PVT systems in Thailand.

\begin{tabular}{lll}
\hline & a-Si PVT & mc-Si PVT \\
\hline Payback [years] & 7.6 & 14.5 \\
Capital cost [THB] & 46,400 & 87,500 \\
Maintenance cost [THB/year] & 2000 & 2000 \\
Annual cost saving [THB/year] & 8219 & 8276 \\
Net saving [THB/year] & 6219 & 6276 \\
\hline
\end{tabular}

By comparing the results of the Cyprus climate reported by Kalogirou [9], the energy production per unit area of his report are $450 \mathrm{kWh} / \mathrm{m}^{2}$ and $144 \mathrm{kWh} / \mathrm{m}^{2}$ for heat output and electrical output respectively (the electrical production of PV only is $52 \mathrm{kWh} / \mathrm{m}^{2}$ ) while the results in Thailand show the values are $1.14 \times 10^{3} \mathrm{kWh} / \mathrm{m}^{2}$ and $72 \mathrm{kWh} / \mathrm{m}^{2}$. It can be said that PVT collectors working under Bangkok's climate make more high performance in thermal energy aspect and lower electrical production than that found in Cyprus. One reason is that the average ambient temperature that directly influences electricity output is lower in Cyprus than that of Thailand. 


\subsection{Thermal and Electrical Efficiency}

Figures 12 and 13 show the comparison between the thermal efficiency and electrical efficiency of PVT collectors. For cell efficiency, the monthly deviation of a-Si PVT seems more stable than mc-Si PVT that resulted from the lower value of temperature coefficient of a-Si PV cell. For thermal efficiency, the maximum is occurred in March, which is, summer in Thailand. The behavior of the thermal efficiency are similar for a-Si and mc-Si PVT systems. The average annual efficiencies of electricity and heat production are shown in Table 3.

Figure 12. Cell efficiency of experimental PVT collector.

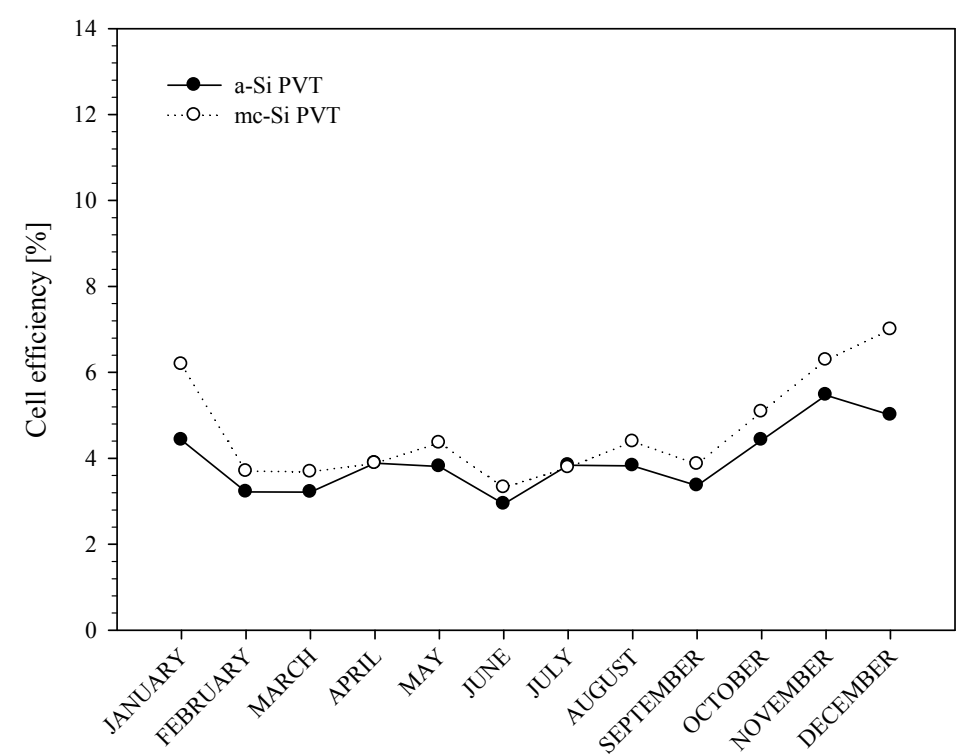

Figure 13. Thermal efficiency of experimental of PVT collector.

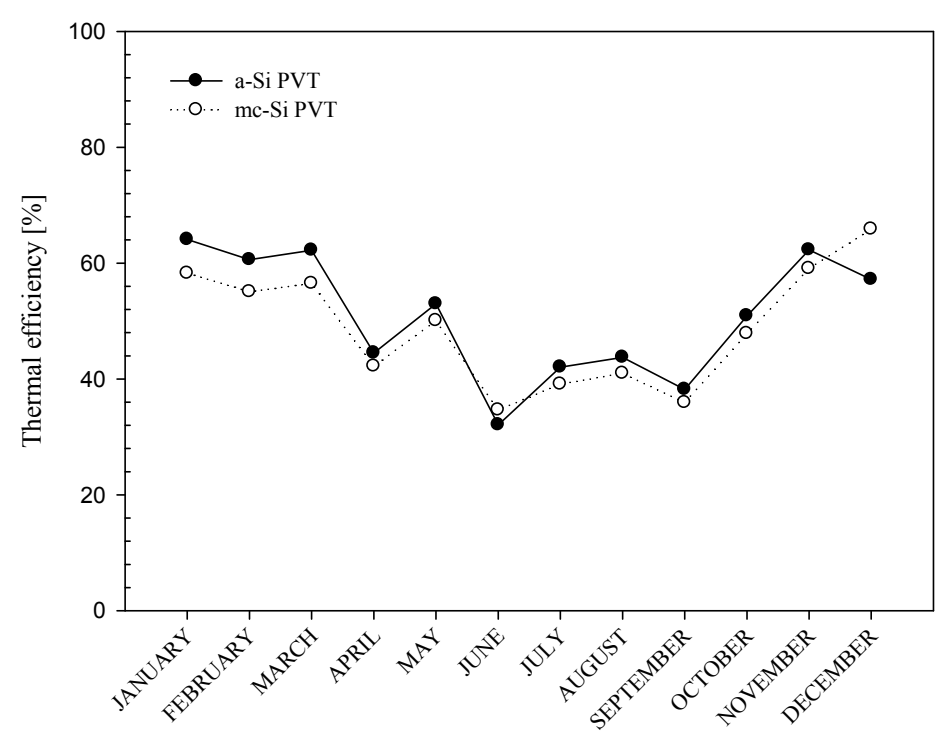

Table 4. The summary of average annual cell and thermal efficiency for PVT collectors.

\begin{tabular}{lll}
\hline & a-Si PVT & mc-Si PVT \\
\hline Cell efficiency [\%] & 4.0 & 4.6 \\
Thermal efficiency [\%] & 51 & 49 \\
\hline
\end{tabular}




\subsection{Economic Analysis}

Economic performance is another important index for users to make their decision to employ PVT systems. Typically, the economic analysis is presented in terms of payback year. For this study the payback year were calculated as simple payback by the consideration of energy output and total costs (capital cost and yearly maintenance cost) of PVT system. The capital and yearly maintenance cost has been investigated by National Science and Technology Development Agency (NSTDA), Thailand in recent years. The evaluation was conducted based on the following assumptions.

- Net savings cost is equal to total savings subtracted by yearly maintenance costs (use $2000 \mathrm{THB} /$ year for this study);

- Electricity price provided by The Energy Policy and Planning Office (EPPO) (April 2011) is $2.98 \mathrm{THB} / \mathrm{kWh}$ and the electricity was converted to heat by using an electrical heater with conversion efficiency of $70 \%$;

- The price of PV panels is an actual selling price provided by suppliers in Bangkok in 2010;

- The costs of each system component including labor costs were estimated with approximate prices in April 2011 in Bangkok.

Table 4 shows the net savings of PVT systems in Thai Baht. The results show that the fastest payback year is 7.5 for a-Si PVT and 14 for mc-Si PVT system. By comparing in economical aspect with other countries, for example, with Cyprus, the PVT for Bangkok gave longer year than that of Cyprus case (4.6 year). It implies that further reduction of the capital cost of PVT systems is necessary to improve its economic competitiveness.

\section{Discussion}

\subsection{PVT Performance versus Solar Irradiation}

Figure 14 shows the multiple liner-regression plots of solar radiation and energy outputs of both types of PVT collectors. Because June is exceptional due to rainy season, the data of June were excluded for the regression analysis. It can be seen from the graph that thermal energy recovery increases as the solar irradiation increases. The relationship between thermal energy outputs and solar irradiation was expressed as $y=y_{0}+a \cdot x_{1}+b \cdot x_{2}$, where $y=$ thermal energy outputs $\left(\mathrm{MJ} /\left(\mathrm{m}^{2} \cdot\right.\right.$ day $\left.)\right)$, $x_{1}=$ solar irradiation $\left(\mathrm{MJ} /\left(\mathrm{m}^{2} \cdot\right.\right.$ day $\left.)\right)$ and $x_{2}=$ dummy variable to represent relatively high performance months and low performance months. In the months of April, July, August and September, the energy recovery was lower than that in the other months. Therefore, the authors distinguished these months from the other months. The low performance months have $x_{2}$ of one while the other months have $x_{2}$ of zero. The estimated formulas for heat outputs are shown as follows.

$$
\begin{aligned}
& \text { a-Si PVT: } y=-0.60+0.59 x_{1}-3.0 x_{2}\left[R^{2}=0.82\right] \\
& \text { mc-Si PVT: } y=1.53+0.47 x_{1}-2.78 x_{2}\left[R^{2}=0.77\right]
\end{aligned}
$$

Here, $R$ indicates the correlation coefficient of the regression. 
Figure 14. Regression plot between solar irradiation and energy outputs (data of June are excluded).

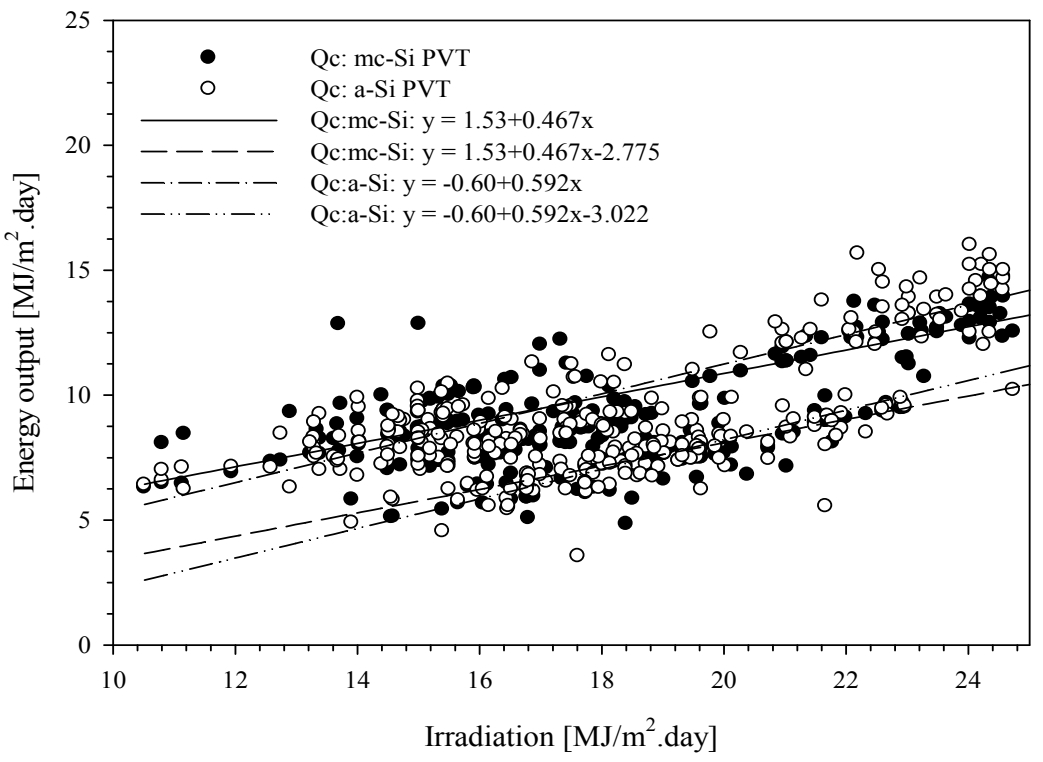

Figure 15 shows the electrical outputs versus solar irradiation, the plots show that the electricity production slightly increases with the solar irradiation. The figure also shows that the electrical production of mc-Si PVT seems scattered than that of a-Si PVT. With these experimental results, the energy output of PVT systems can be roughly estimated based on the solar irradiation except for June because of the rainy season in Thailand.

Figure 15. Regression plot between solar irradiation and electrical outputs (data of June are excluded).

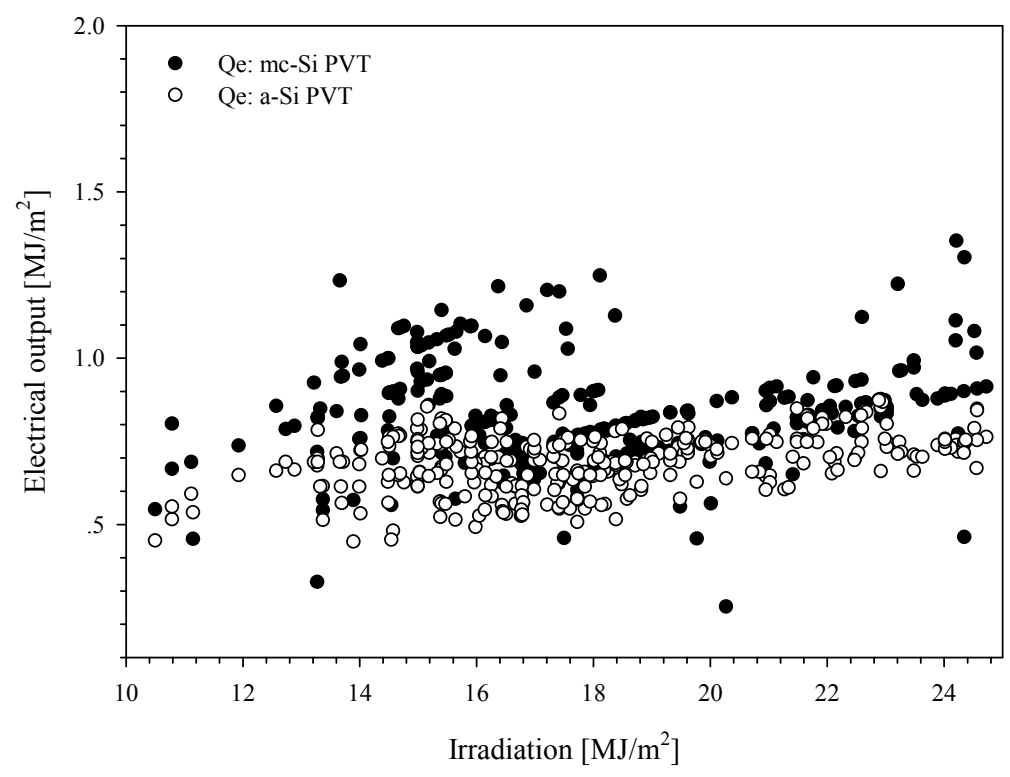

Further measurement of PVT performance is required to elaborate the experimental expression on the relationship between energy output and solar irradiation. 


\subsection{Solar Factor}

Figure 16 shows the solar factor for unit collector area in term of thermal energy outputs that covered heat demand. The value of solar factor is in the range of $0.3-0.7$ for a-Si PVT and $0.3-0.65$ for mc-Si PVT. The maximum solar factors occurred in March for both types of PVT system. The result also shows that the average value of solar factor throughout the year is 0.45 for both types of PVT, which means that the selected absorber area of $2 \mathrm{~m}^{2}$ is enough for typical use in Bangkok.

Figure 16. Solar factor of both types PVT collectors (per one square meter).

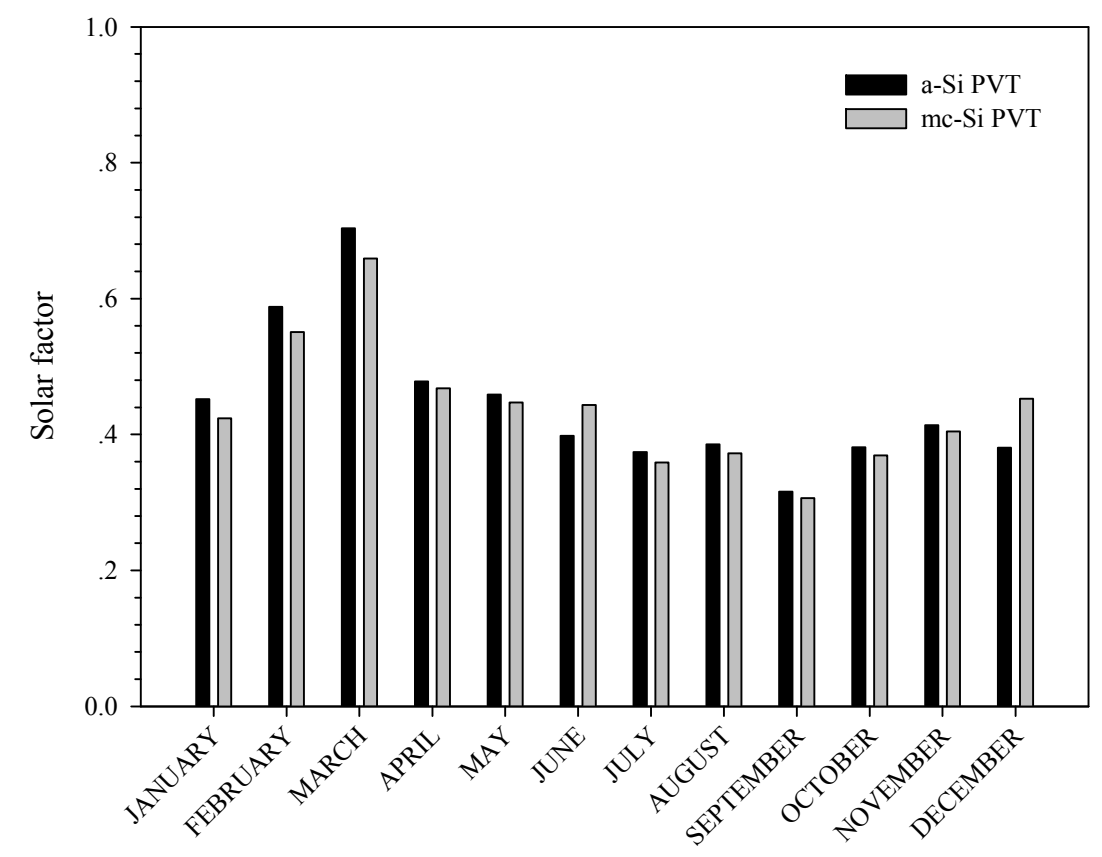

\subsection{Comparison between $a-S i$ and $m c-S i$ PVT}

While a-Si PVT and mc-Si PVT produce almost similar amounts of heat, mc-Si PVT generates 1.3 times more electricity than a-Si PVT does. Considering the electrical efficiency of mc-Si PVT is twice as high as that of a-Si PVT, it can be said that electricity generation performs less than it is expected from the nominal efficiency. It may be caused by the temperature effect. It also results in economical disadvantages of mc-Si because mc-Si PV cells cost much higher than a-Si PV cells.

\section{Conclusions}

In this study, the performance of PVT systems was examined under actual climate conditions in Bangkok to show how much electricity and heat could be supplied in tropical areas. It was assumed that the PVT systems were used in a medium-sized household in Bangkok. Two kinds of PV cells, i.e., a-Si and mc-Si, were tested and compared. The following was found from the measured results.

- The maximum energy outputs of both types of PVT collectors occurred in March under the highest monthly irradiation. PVT systems in Bangkok annually produced $1.1 \times 10^{3} \mathrm{kWh} / \mathrm{m}^{2}$ of heat as well as $55-83 \mathrm{kWh} / \mathrm{m}^{2}$ of electricity. Approximately $50 \%$ of solar input can be converted into thermal energy while $4-5 \%$ turns into electricity. 
- Either a-Si or mc-Si PVT recovers almost the same amount of heat. On the other hand, mc-Si PVT supplies 1.2 times as much electricity as a-Si PVT because the former has higher nominal efficiency. It should be noted that relatively high ambient temperatures in Bangkok decreases the performance of electricity generation of mc-Si PV cells.

- Based on the comparison of the energy outputs of PVT systems in this study with other PVT systems working under different locations such as Cyprus in Europe, the thermal output of PVT under Bangkok climate is higher than that in Cyprus with the same unit collector area, In contrast, the electrical output in Bangkok is lower, which is a result of the effect that annual ambient temperatures in Bangkok which are higher than that of Cyprus.

- For the economical aspect, the payback years of PVT is 8 and 15 years for a-Si PVT and mc-Si PVT respectively. The payback years of both systems working in Bangkok are acceptable because the system lifetime is expected 20 years. In addition, the results show that the payback of PVT in Bangkok is longer than that in Cyprus.

The results of this study suggest that PVT technology is useful and feasible to supply heat and electricity for residential applications in tropical regions. The development of PVT systems is still required to reduce the system cost and to enhance economical merit in order to promote PVT technology widely in South Eastern Asia.

\section{References}

1. Janjai, S. Solar Radiation Map of Thailand Developed Using Satellite Data and Ground-Based Meteorological Data; Technical Report; Department of Alternative Energy Development and Efficiency, Ministry of Energy: Bangkok, Thailand, 1999.

2. Chow, T.; He, W.; Ji, J. Hybrid photovoltaic-thermosyphon water heating system for residential application. Sol. Energy 2006, 80, 298-306.

3. Bakker, M. Outdoor performance of uncovered PV/thermal. In Proceedings of 19th European PV Solar Energy Conference and Exhibition, Paris, France, June 2004.

4. Tripanagnostopoulos, Y. Hybrid photovoltaic/thermal solar systems. Sol. Energy 2002, 72, 217-234.

5. Hisashi, S. Field experimental and analyses on a hybrid solar collector. Appl. Therm. Eng. 2003, 23, 2083-2105.

6. Nakajima, A. Spectral Effect of a single-junction amorphous silicon solar cell on outdoor performance. Jpn. J. Appl. Phys. 2004, 43, 2425-2431.

7. Zondag, A. The yield of different combined PV-thermal collector designs. Sol. Energy 2003, 74, 253-269

8. Florschuetz, L. Extension of the Hottel-Whillier model to the analysis of combined photovoltaic/thermal flat plate collector. Sol. Energy 1979, 22, 361-366.

9. Soteris A.K. Use of TRNSYS for modeling and Simulation of a hybrid PV-thermal solar system for Cyprus. Renew. Energy 2001, 23, 247-260.

10. Maurice, J. System studies on combined PV/thermal PANELS. In Proceedings of 9th International Conference on Solar Energy in High Latitudes, Leiden, The Netherlands, May, 2001. 
11. Vokas, G.; Christandonis, N.; Skittids F. Hybrid photovoltaic-thermal systems for domestic heating and cooling - a theoretical approach. Sol. Energy 2006, 80, 607-615.

12. Beccali, M.; Finocchiaro, P.; Nocke, B. Energy and economic assessment of desiccant cooling systems coupled with single glazed air and hybrid PV/thermal solar collectors for applications in hot and humid climate. Sol. Energy 2009, 83, 1828-1846.

13. Sukamongkol, Y.; Chungpaibulpatana, S.; Limmeechokchai, B.; Sripadungtham, P. Condenser heat recovery with a PV/T air heating collector to regenerate desiccant for reducing energy use of an air conditioning room. Energy Build. 2010, 42, 315-325.

14. Adsten, M.; Perers, B.; Wackelgard, E. The influence of climate and location on collector performance. Renew. Energy 2002, 25, 499-509.

15. Manual of TRNSYS (version 16); Solar Energy Laboratory, University of Wisconsin-Madison: Madison, WI, USA, 2005.

16. Van Helden, W.G.J.; van Zolingen, R.J.Ch.; Zondag, H.A. PV thermal systems: PV panels supplying renewable electricity and heat. Prog. Photovolt. Res. Appl. 2004, 12, 415-426.

17. Tripanagnostopoulos, Y.; Souliotis, M.; Battisti R.; Corrado, A. Energy cost and LCA results of PV and hybrid PV/T solar systems. Prog. Photovolt. Res. Appl. 2005, 13, 235-250.

(C) 2012 by the authors; licensee MDPI, Basel, Switzerland. This article is an open access article distributed under the terms and conditions of the Creative Commons Attribution license (http://creativecommons.org/licenses/by/3.0/). 